\title{
Ideological Codependency and Regional Order: Iran, Syria, and the Axis of Refusal
}

\author{
Ewan Stein, University of Edinburgh
}

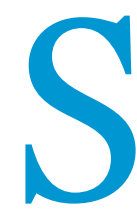

tudents of Middle East international politics struggle to reconcile two apparently contradictory accounts of their underlying logic. Some view the region as a quintessentially Hobbesian environment, in which calculated self-interest prevails. Others see it as an arena in which states ally with actors sharing their sectarian, ethnic, and ideological identities. Even if not all accounts in the latter category accept simplistic notions of age-old religious conflict, many assume that one of the principal fault lines in the Middle East today runs between the Sunni and Shi'i sects in Islam. ${ }^{1}$ Sectarian qualifiers have become routine in much reportage-and scholarship-on Middle East international politics. Saudi Arabia, Turkey, and Qatar, as well as Syrian opposition groups, are frequently qualified as being "Sunni," whereas Iran, Hizbullah, and the Assad regime in Syria are increasingly not mentioned without reference to their "Shi'i" identity.

Although the idea that the states of the Muslim world pursue peculiarly "Islamic" foreign policies was debunked some time ago (Piscatori 1986), issues related to identity have become increasingly prominent in general international relations (IR) scholarship, as a result in no small part of interventions derived from studies of the Middle East (Stein 2012). With exceptions, "identity" has eclipsed "ideology" as an analytical category in scholarship on the Middle East since the end of the Cold War (Haugbolle 2016). When they are considered important, political ideologies often are approached narrowly as systems of ideas informing elite perceptions or as forms of "soft power." This article argues that a more sociological understanding of ideology can refine and add nuance to our understanding of the ideational drivers of foreign policy, alliance choice, and regional order in general. To demonstrate its utility, I offer an explanation for Iran's alliance with Syria based on the notion of "ideological codependency."

The article addresses several of the engagement strategies specified by Valbjørn in his contribution to this symposium. It speaks to issues of continuity and change in regional order and examines how dynamics at the societal or "mass" level shape the ideological power of populist regimes and factions. "Politics from below" directly influence the foreign-policy behavior of these actors and, by extension, are central to the reproduction and transformation of regional order. The article also contributes to the "de-exceptionalization" of Middle East politics. Identity dynamics at the societal level, or what often is imprecisely dubbed "the Arab Street," are frequently blamed for the region's propensity for conflict due to fiercely held ethnic and religious loyalties. However, I argue that it is in relation to "organic ideology"-and not identity per se-that the role of ideas should be understood. The article also engages with the issue of power in IR, particularly the salience of ideology as a form of power. Ideological power constitutes a fundamental currency in both domestic politics and IR, with the interrelationship between the two often obscured by a narrower focus on ideology as a source of legitimacy, shaper of perception or foreign-policy resource (i.e., soft power). Finally, the article engages directly with issues of identity in IR, specifically by integrating ideology as a category of analysis.

These issues are central to a wide range of IR literatures, including varieties of "second-image" analysis, which-as distinct from systemic theories such as neo-realism and constructivism-attach importance to variations in the internal characteristics of states, including the ideological orientations of regimes. They are also relevant to literature on the role of ideas, identity, and ideology in the constitution of regional order. Examples include work on coalitions and regional security (Buzan and Wæver 2003; Solingen 1998, 2015), neoclassical realism (Juneau 2015), role theory (Cantir and Kaarbo 2012; Fernandez-Molina 2015), the role of ideology in alliances and conflict (Haas 2012; Owen 2010, 2015; Rubin 2014), the foreign policy of authoritarian states (Colgan and Weeks 2015; Kanat 2014; Odinius and Kuntz 2015; Weeks 2012), and constructivist approaches to foreign policy and regional order (Barnett 1998; Telhami and Barnett 2002).

Two assumptions underpin most of these approaches. The first is an interpretation of ideology and identity as bounded and autonomous categories that shape actors' perceptions of interests, friends, and enemies, or confer general regime legitimacy. Second, although some scholars explain divergent outlooks with reference to historical processes of state formation (Solingen 2015), such an explanation is provided as background rather than theorized as an integral and ongoing influence on foreign policy and regional order. Societal beliefs are considered as one among many "inputs" in the foreign-policy process, not in relation to a regime's ideological power.

Populist authoritarian regimes, in particular, depend preponderantly on ideology as a source of power both to 
gain societal approval for specific policies and to sustain their dominant positions within states. Ideology pervades public spheres to shape conceptions of national identity, legitimizing some political narratives while delegitimizing others. Populist ideological claims, however, must be validated through action. Unsubstantiated claims to be acting in the people's interests weaken a regime's ideological power, whereas demonstrable political and foreign-policy successes compensate for such losses. These dynamics, as illustrated herein, are essential to understanding certain foreign-policy strategies and alliance choices.

\section{IDEATIONAL FACTORS IN FOREIGN POLICY AND IR}

Ideology lies at the core of modernity, in which political power depends on the consent and support of putatively sovereign publics, not only the possession of material resources (i.e., economic and military) (Gramsci 1971; Mann 1986). For Gramsci $(1971,376)$, "willed" or "arbitrary" ideologies should be distinguished from "organic" ideologies, which "are necessary to a given structure." In the Middle East context, Ba'thism and Islamism represent "willed" ideologies, but their contribution to general ideological power rests on the resonance they have with broader organic ideologies through which individuals "acquire consciousness of their position" (ibid.). Ideological hegemony depends on this congruency with political subjectivities that are integral to the structure of power in modern states.

A regime's ideological hegemony can be augmented or lost through domestic and foreign policy. Middle East regional politics play out within a common ideological space, stemming from the interactive historical development of the region's states and social movements. Promises to redistribute wealth and increase political inclusion, alongside opposition to imperialism and Zionism, constituted central motifs for the movements that consolidated state power in Iran, Syria, Egypt, and elsewhere, emanating as they did from the "organic ideology" of the publics that supported them. Populist governments view themselves as champions of the people's will against the predations of a corrupt elite (Abrahamian 1993; Holliday 2016; Verbeek and Zaslove 2015). instantiation of "the people" in general for populist regimes, whose claims to fulfill the needs and aspirations of their own people are no longer credible. ${ }^{2}$ The need to protect this power resource creates ideological codependencies among regional populists, of which the Iranian and Syrian regimes-despite partial moves away from populism since the 1990s-represent the paramount examples in the contemporary Middle East.

\section{EXPLAINING THE IRANIAN INTERVENTION IN SYRIA}

As with Middle Eastern IR in general, the Iran-Syria relationship tends to be understood in terms of either identity or geopolitics. Accounts that attribute the alignment to primordial identifications are easily challenged by pointing out the constructed and fluid nature of sectarian identity and the existence of cross-sect alliances, as well as the correlative rather than causal character of sectarianism in regional confrontations (Gause 2014; Juneau 2016). More subtle approaches to identity as a driver of Iranian policy toward Syria focus on the symbolic importance to Iran of maintaining a so-called axis of refusal, comprising Syria and Hizbullah, as well as the Palestinian Islamist groups, Hamas and Islamic Jihad. The importance of the axis for Iran, in such accounts, lies in its substantiation of Iran's identity as an opponent of Western imperialism (Fawcett 2015). In turn, this prestige rests on the regional resonance of anti-Zionism, anti-imperialism, and solidarity with the "downtrodden" Muslim masses, toward which Iran's revolutionary identity is directed. However, this regional identity-based explanation struggles to explain why Iran would support a regime the standing of which among most publics in the region has reached rock bottom. The prestige of Hizbullah, previously a glowing advertisement for the vitality of the Islamic Revolution, also has plummeted as a result of its role in the Syrian civil war. Iran's identity as champion of the downtrodden in the Muslim world has been seriously undermined, despite its dogged commitment to preserving the axis of refusal.

According to more realist explanations, Iran needs Syria so that it can reliably arm and fund Hizbullah, the better to threaten Israel and boost its power and influence in the

\section{In the Middle East context, Ba'thism and Islamism represent "willed" ideologies, but their contribution to general ideological power rests on the resonance they have with broader organic ideologies through which individuals "acquire consciousness of their position."}

Failure to deliver on domestic promises to improve the material condition of the masses led regimes to rely more on anti-imperialism and anti-Zionism to substantiate their conformity with organic ideology. The growing need of populist regimes to engage politically and economically with the West often meant that the most direct way to achieve this substantiation was through supporting the Palestinians against Israel. Palestine has come to embody the de facto
Levant. Indeed, Hizbullah has leveraged its impressive military capability and its network of Iranian-funded social services to sustain local popularity and create problems for Israel. It also has deterred a US or Israeli strike on Iran. However, Iran risked and expended much for what could never be more than a limited deterrent. Were Israel and the United States ever to plan a large-scale assault on Iran, Hizbullah could do little to prevent it. 
A related geopolitical explanation often advanced for Iran's support for Hizbullah, as well as Hamas and the Palestinian Islamic Jihad, rests on these groups' utility as "spoilers" of an Israel-Palestine peace process deemed central to the further consolidation of US power in the region. However, there has been no such process to spoil since at least 2000, and the Palestinian people have proven themselves more than capable of rejecting unjust peace settlements without Iran's help. The frequent equation of Palestinian popular resistance with Iranian-financed terrorism in Western and Israeli media discourse should be treated as propaganda rather than as an accurate reflection of Iranian influence in Palestinian activism.

\section{IDEOLOGICAL CODEPENDENCY}

Ideological compatibility tends to be discounted as an explanation for the Syria-Iran alliance. Islamist Iran and secular Ba'thist Syria, after all, should have little in common on the level of ideas. However, the ideological mismatch between two allies appears puzzling only if we treat ideas narrowly (as willed ideology) rather than taking into account their relation with deeper organic ideology. 3 Both Ba'thism and Islamism resonate within a common regional ideological space. Core tenets of each include (1) a commitment to the liberation of "the people" from corrupt elites kept in place by imperialism and Zionism; and (2) a conception of "the people" that transcends the borders of the nation-state: the Arabs in the case of the Ba'th Party and Muslims for the Islamic Republic. Pan-Arabism and Pan-Islamism are not neutral expressions of shared heritage. Revolutionary intellectuals and social movements have "ideologized" ethnic and religious identities and directed them toward the struggle for social emancipation and liberation from imperialism. Organic ideology in the Middle East reflects the accumulated collective memory of contentious politics, war and revolution, framed and given meaning within social movements. Engaging with such sentiments through "willed" ideology forms the bedrock of the Iranian and Syrian regimes' ideological power.

Both Iran and Syria embarked upon redistributive economic policies aimed at mobilizing marginalized classes and breaking the power of the old oligarchies. In Syria (from 1963, but especially from 1970) and Iran (from 1979), the strengthening and proliferation of political and bureaucratic structures- in the interests of "the people." In line with global trends, they evolved in a post-populist direction. The Ba'th Party under Hafiz al-Assad steadily became an instrument of topdown control for the regime rather than one of revolutionary mobilization (Ehteshami and Hinnebusch 1997). Until the 1990s, the regime could credibly claim to exchange political freedom for economic redistribution-a key element of the populist authoritarian social contract. Since then, however, social welfare has scaled back and neoliberal economic policies have deepened inequality (Dahi and Munif 2012). The regime diversified its support base to include a chronyistic private-sector bourgeoisie linked to the state via patronclient relations. This reflects a transition from populism to post-populism in economic and social terms, but ideological change has not kept pace. Bashar al-Assad has relied increasingly on force and Syria's demonstrable activism on behalf of the Palestinian people as the pivot of an "axis of refusal." His regime thus derives domestic ideological power from the "resistance" credentials of its external allies in Iran, as well as non-state allies, Hizbullah and Hamas (El-Hokayem 2007; Sottimano 2016).

The populist regime of Khomeini also came under pressure in the context of Iran's war with Iraq. In the 1990s, under Rafsanjani and Khatami, Iran moved some way toward economic and political liberalisation; however, the populist authoritarian core of the regime remained dominant. The fact that reformists broadly accept the legitimacy of vilayet-e faqih means that much dissent can be absorbed within the system. At the same time, populist factions in Iran, clustered around the Supreme Leader, are unable to rely on purely domestic policies to rally their base and neutralize calls for reform (Dorraj and Dodson 2009). Like Assad's regime in Syria, foreign policy fills the ideological void. For Iranian populists, Bashar al-Assad is useful precisely because he is so reliant on the Iranian-led axis of refusal for his regime's survival. A regime in Syria based on alternative sources of power would not have such an existential need for Iranian support. Foreign policy can be considered to serve a "diversionary" or "internalist" function in the sense that it distracts from problems at home (Halliday 1994; Kanat 2014). However, diversionary foreign policy in this case provides not only a short-term palliative. Rather, it also reinforces the power of Syrian and Iranian regimes whose socioeconomic promises

\section{For Iranian populists, Bashar al-Assad is useful precisely because he is so reliant on the Iranian-led axis of refusal for his regime's survival.}

and their penetration into almost all areas of life-blurred the distinction between regime and state and even between state and society. The state was able to exert considerable control over ideas, making any challenge to its willed ideology not only politically risky but also tantamount to treason.

However, the Syrian and Iranian regimes also experienced a progressive diminution of their ideological power, manifest in their declining ability to credibly claim to be acting are wearing thin but who are unwilling to fully yield their positions of dominance to competing domestic actors.

The fact that populist regimes come together with nonstate actors in common cause reflects the extent to which the struggle against imperialism and Zionism, and the defense of the Palestinian people, have become "common sense" to publics across the region. The axis of refusal serves domestic-power interests for regimes by reinforcing their 
ideological hegemony. This mutually reinforcing dynamic can be understood as ideological codependency. Although Iran has spent billions of dollars defending the Syrian regime during the current civil war, it is not in a position to use financial resources to establish with the Syrian regime the type of ongoing economic-dependency relationship that binds, for example, the Egyptian regime to that of Saudi Arabia. Rather, Syria is something of an ideological client state. Understood this way, the interrelationship between the domestic and international functions of ideology-as a dominant form of power for populist actors-emerges clearly. In Iran, the ideological support given to Syria substantiates the authoritarian regime's claims to be acting in the interests of the people. The Islamic Revolutionary Guard Corps (IRGC)-the most powerful political actor in Iran and the one most wedded to the Islamic Republic's populist characterhas energetically championed and prosecuted the war in Syria despite objections from other less-populist factions (Tomlinson 2012). However, the populist IRGC, on which the Supreme Leader Ayatollah Khamenei depends, prevailed (Hokayem 2014).

\section{CONCLUSION}

In seeking to explain Iranian support for the Assad regime, this intervention raises two important issues for IR theory. The first is to introduce a more sociological understanding of the role of ideology-particularly the notion of ideological codependence among regional actors-to IR. Ideological power can be gained and lost through foreign policy. National identity for populist regimes is predominantly "ideology-based," meaning that ideological power assumes considerable importance within the overall power configuration. Although space limitations prevent further reflection, we also might expect that "post-populist" states-wherein populist actors have lost state power-will seek to devalue ideological power in general as a currency in regional politics.

The second issue relates to the importance of "politics from below" for understanding foreign-policy strategies and regional order. Populist regimes suffer diminution in their ideological and, therefore, general power when they cannot deliver on their domestic economic promises. Without the resources to address domestic ills, these regimes turn to foreign policy and the cultivation of ideological codependencies. In the Middle East, these predominantly revolve around the struggle against imperialism and Zionism through the defense of Palestine, as a type of surrogate for "the people" in whose interests they must be seen to act. Societal pressure in the face of the growing chasm between ideological claims and material reality fueled Bashar al-Assad's commitment to supporting an external alliance devoted to the Palestinian cause. The failure of this strategy, demonstrated by the uprising in Syria, prompted Iran to intervene with military and economic support for its Ba'thist ally. That this policy was maintained despite its unpopularity among Arab publics at large is testimony to the centrality of the axis of refusal to the domestic ideological, and therefore general, power of populist forces in the contemporary Middle East.

\section{NOTES}

1. For recent-among countless-examples of this perspective, see Baxter and Simpson (2015) and Djalili and Kellner (2014). See also Gause (2014) for additional discussion.

2. This also can be understood through the lens of societal insecurity. See the Hazbun and Bilgin contributions in this issue.

3. This observation has implications for the notion of "ideological multipolarity." See the Gause contribution in this issue. It also raises questions for how we interpret the rise of transnational ideologies and identities as power resources for regimes, as discussed in Salloukh's contribution in this issue.

\section{REFERENCES}

Abrahamian, Ervand. 1993. Khomeinism: Essays on the Islamic Republic. Oakland: University of California Press.

Barnett, Michael. 1998. Dialogues in Arab Politics: Negotiations in Regional Order. New York: Columbia University Press.

Baxter, Kylie and Kumuda Simpson. 2015. "The United States and Saudi Arabia through the Arab Uprisings." Global Change, Peace \& Security 27 (2): 139-51.

Buzan, Barry and Ole Wæver. 2003. Regions and Powers: The Structure of International Security. Cambridge and New York: Cambridge University Press.

Cantir, Cristian and Juliet Kaarbo. 2012. "Contested Roles and Domestic Politics: Reflections on Role Theory in Foreign Policy Analysis and IR Theory." Foreign Policy Analysis 8 (1): 5-24.

Colgan, Jeff D. and Jessica L. P. Weeks. 2015. "Revolution, Personalist Dictatorships, and International Conflict." International Organization 69 (1): 163-94.

Dahi, Omar S. and Yasser Munif. 2012. "Revolts in Syria: Tracking the Convergence Between Authoritarianism and Neoliberalism." Journal of Asian and African Studies 47 (4): 323-32.

Djalili, Mohammad-Reza and Thierry Kellner. 2014. "Iran's Syria Policy in the Wake of the 'Arab Springs.” Turkish Review 4 (4): 396-405.

Dorraj, Manochehr and Michael S. Dodson. 2009. "Neo-Populism in Comparative Perspective: Iran and Venezuela." Comparative Studies of South Asia, Africa and the Middle East 29 (1): 137-51.

Ehteshami, Anoushiravan and Raymond A. Hinnebusch. 1997. Syria and Iran: Middle Powers in a Penetrated Regional System. London and New York: Routledge.

El-Hokayem, Emile. 2007. "Hizballah and Syria: Outgrowing the Proxy Relationship." The Washington Quarterly 30 (2): 35-52.

Fawcett, Louise. 2015. "Iran and the Regionalization of (In)security." International Politics 52 (5): 646-56.

Fernandez-Molina, Irene. 2015. Moroccan Foreign Policy under Mohammed VI, 1999-2014. London: Routledge.

Gause, F. Gregory III. 2014. Beyond Sectarianism: The New Middle East Cold War. Doha, Qatar: Brookings Doha Center Analysis Paper.

Gramsci, Antonio. 1971. Selections from the Prison Notebooks of Antonio Gramsci. Eds. Quintin Hoare and Geoffrey Nowell Smith. London: Lawrence \& Wishart.

Haas, Mark L. 2012. The Clash of Ideologies: Middle Eastern Politics and American Security. New York and Oxford: Oxford University Press.

Halliday, Fred. 1994. Rethinking International Relations. Basingstoke, England: Macmillan.

Haugbolle, Sune. 2016. "In Defense of Ideology: Notes on Experience and Revolution." In Project on Middle East Political Science. Available at http://pomeps.org/2016/o5/31/in-defense-of-ideology-notes-on-experienceand-revolution. Accessed July 21.

Hokayem, Emile. 2014. "Iran, the Gulf States and the Syrian Civil War." Adelphi Series 54 (447-448): 39-70.

Holliday, Shabnam J. 2016. “The Legacy of Subalternity and Gramsci's National-Popular: Populist Discourse in the Case of the Islamic Republic of Iran." Third World Quarterly 37 (5): 917-33.

Juneau, Thomas. 2015. Squandered Opportunity: Neoclassical Realism and Iranian Foreign Policy. Stanford, CA: Stanford University Press.

. 2016. "Iran's Policy towards the Houthis in Yemen: A Limited Return on a Modest Investment." International Affairs 92 (3): 647-63.

Kanat, Kilic. 2014. "Diversionary Foreign Policy in Authoritarian States: The Use of Multiple Diversionary Strategies by Saddam Hussein during the Gulf War." Journal of Strategic Security 7 (1): 15-32. 
Mann, Michael. 1986. The Sources of Social Power. Vol. 1: A History of Power from the Beginning to A.D. 176o. Cambridge and New York: Cambridge University Press.

Odinius, Daniel and Philipp Kuntz. 2015. "The Limits of Authoritarian Solidarity: The Gulf Monarchies and Preserving Authoritarian Rule during the Arab Spring." European Journal of Political Research 54 (4): 639-54.

Owen, John M. 2010. The Clash of Ideas in World Politics: Transnational Networks, States, and Regime Change, 1510-2010. Princeton, NJ: Princeton University Press.

- 2015. Confronting Political Islam: Six Lessons from the West's Past. Princeton, NJ, and Oxford: Princeton University Press.

Piscatori, James P. 1986. Islam in a World of Nation-States. Cambridge and New York: Cambridge University Press.

Rubin, Lawrence. 2014. Islam in the Balance: Ideational Threats in Arab Politics. Stanford, CA: Stanford University Press.

Solingen, Etel. 1998. Regional Orders at Century's Dawn. Princeton, NJ: Princeton University Press.

. 2015. Comparative Regionalism: Economics and Security. London: Routledge, Taylor \& Francis Group.
Sottimano, Aurora. 2016. "Building Authoritarian 'Legitimacy': Domestic Compliance and International Standing of Bashar Al-Assad's Syria.” Global Discourse 6 (3): 450-66.

Stein, Ewan. 2012. "Beyond Arabism vs. Sovereignty: Relocating Ideas in the International Relations of the Middle East." Review of International Studies 38 (4): 881-905.

Telhami, Shibley and Michael Barnett. 2002. "Introduction: Identity and Foreign Policy in the Middle East." In Identity and Foreign Policy in the Middle East, eds. Shibley Telhami and Michael Barnett, 155-69. Ithaca, NY: Cornell University Press.

Tomlinson, Hugh. 2012. "Tehran Split over Billions Spent by Spy Chief to Prop up Assad Regime; Iran.” The Times, 23.

Verbeek, Bertjan and Andrej Zaslove. 2015. "The Impact of Populist Radical Right Parties on Foreign Policy: The Northern League as a Junior Coalition Partner in the Berlusconi Governments." European Political Science Review 7 (4): 525-46.

Weeks, Jessica L. 2012. "Strongmen and Straw Men: Authoritarian Regimes and the Initiation of International Conflict." American Political Science Review 106 (2): 326-47. 